\title{
Effects of gabapentin on pain and opioid consumption after abdominal hysterectomy
}

\author{
Fatemeh Frouzanfard MD1, Mohammed Reza Fazel MD², Azadeh Abolhasani MD , Esmaeil Fakharian MD², \\ Golmabas Mousavi $\mathrm{PhD}^{3}$, Alireza Moravveji $\mathrm{PhD}^{4}$
}

F Frouzanfard, MR Fazel, A Abolhasani, E Fakharian, G Mousavi, A Moravveji. Effects of gabapentin on pain and opioid consumption after abdominal hysterectomy. Pain Res Manag 2013;18(2):94-96

BACKGROUND: Postoperative pain is an important factor affecting anesthesia and surgery.

OBBJECTIVES: The present study assessed the effects of $1200 \mathrm{mg}$ gabapentin, an anticonvulsant drug that acts through voltage-dependent calcium channels, for the control of postoperative pain in patients undergoing abdominal hysterectomy.

METHODS: Fifty patients undergoing hysterectomy were enrolled in the present study. Subjects received either $1200 \mathrm{mg}$ gabapentin or placebo $2 \mathrm{~h}$ before surgery. The amount of morphine consumption and level of postoperative pain at $2 \mathrm{~h}, 6 \mathrm{~h}, 12 \mathrm{~h}$ and $24 \mathrm{~h}$ after surgery were measured.

RESULTS: There were no significant differences in age, duration of surgery and anesthesia, or body mass index between the two groups. The mean intensity of pain in the gabapentin group was significantly lower than in the placebo group. The mean amount of morphine used in the placebo group $(5.2 \pm 2.8 \mathrm{mg})$ was significantly higher than in gabapentin group $(1.2 \pm 0.29 \mathrm{mg} ; \mathrm{P}=0.001)$. Nausea and vomiting in the placebo group was more common than in the gabapentin group $(\mathrm{P}=0.001)$. The time interval for initial ambulation after surgery was significantly shorter in the gabapentin group $(12.24 \pm 2.18 \mathrm{~h})$ compared with the placebo group ( $15 \pm 3.61 \mathrm{~h} ; \mathrm{P}=0.002)$.

CONCLUSION: $1200 \mathrm{mg}$ gabapentin reduced postoperative pain and the need for opioids, and enabled earlier ambulation of the patient. Significant side effects were not observed.

Key Words: Gabapentin; Hysterectomy; Opioid; Pain; Placebo
Les effets de la gabapentine sur la douleur et la consommation d'opioïdes après une hystérectomie abdominale

HISTORIQUE : La douleur postopératoire est un facteur important qui influe sur l'anesthésie et la chirurgie.

OBJECTIFS : La présente étude visait à évaluer les effets de $1200 \mathrm{mg}$ de gabapentine, un anticonvulsivant qui agit par les canaux calciques voltage-dépendants pour contrôler la douleur postopératoire chez des patientes subissant une hystérectomie abdominale.

MÉTHODOLOGIE : Cinquante patientes qui avaient subi une hystérectomie ont participé à la présente étude. Elles ont reçu soit $1200 \mathrm{mg}$ de gabapentine, soit un placebo deux heures avant l'opération. La quantité de morphine consommée et le taux de douleur postopératoire ressenti ont été mesurés deux heures, six heures, 12 heures et 24 heures après la chirurgie. RÉSULTATS : Il n'y avait pas de différence significative d'âge, de durée d'opération et d'anesthésie ou d'indice de masse corporelle entre les deux groupes. L'intensité moyenne de la douleur dans le groupe prenant de la gabapentine était considérablement plus faible que dans celui prenant un placebo. La quantité moyenne de morphine utilisée dans le groupe prenant un placebo $(5,2 \mathrm{mg} \pm 2,8 \mathrm{mg})$ était considérablement plus élevée que dans celui prenant de la gabapentine $(1,2 \mathrm{mg} \pm 0,29 \mathrm{mg})(P=0,001)$. Les nausées et les vomissements étaient plus courants dans le groupe prenant un placebo que dans celui prenant de la gabapentine $(\mathrm{P}=0,001)$. Après la chirurgie, l'intervalle avant l'ambulation initiale était considérablement plus faible dans le groupe prenant de la gabapentine (12,24 heures $\pm 2,18$ heures) que dans celui prenant un placebo $(15 \mathrm{~h} \pm 3,61 \mathrm{~h} ; \mathrm{P}=0,002)$.

CONCLUSION : Une dose de $1200 \mathrm{mg}$ de gabapentine réduit la douleur postopératoire et les besoins en opioïdes et favorise une ambulation plus rapide du patient. On n'a pas observé d'effets secondaires significatifs.

excluded. After approval by the ethics committee of the university, written informed consent was obtained from all subjects. Using a random number table, the patients were allocated to one of two study groups receiving either $1200 \mathrm{mg}$ gabapentin or placebo $2 \mathrm{~h}$ before surgery. The surgeon and the staff assessing pain and complications postoperatively had no knowledge of the drug assignment.

After entering the operating room, patients received $10 \mathrm{~mL} / \mathrm{kg}$ of Ringer's solution. Heart rate, blood pressure and arterial oxygen saturation were monitored. Anesthesia was induced by thiopental $(6 \mathrm{mg} / \mathrm{kg})$, and atracurium $(0.5 \mathrm{mg} / \mathrm{kg})$ was used to facilitate intubation. Patients were ventilated with $100 \%$ oxygen and intubated with a suitably sized cuffed tube. Anesthesia was maintained using a mixture of oxygen $(50 \%)$, nitrous oxide (50\%) and isoflurane. Atracurium $(0.2 \mathrm{mg} / \mathrm{kg} / \mathrm{h})$ and fentanyl $(2 \mu \mathrm{g} / \mathrm{kg} / \mathrm{h})$ were used for intraoperative relaxation and analgesia. Surgery was performed while patients were supine. After surgery, the muscle relaxants were reversed using neostigmine $(40 \mu \mathrm{g} / \mathrm{kg})$ and atropine $(20 \mu \mathrm{g} / \mathrm{kg})$. After extubation and ensuring adequate ventilation, patients were transferred to the recovery care unit for $2 \mathrm{~h}$ and then to the ward. All patients received $100 \mathrm{mg}$ suppository diclofenac every $6 \mathrm{~h}$. Postoperative pain was measured using a visual analogue scale. Patients with a pain score $>4$ were treated with $5 \mathrm{mg}$ intramuscular morphine. The amount of morphine consumed and pain level at $2 \mathrm{~h}, 6 \mathrm{~h}$, $12 \mathrm{~h}$ and $24 \mathrm{~h}$ after surgery were recorded. Postoperative complications, including vomiting and dizziness, were also recorded. This information,

Fifty patients undergoing hysterectomy (class 1 or 2 of the American Society of Anesthesiology) admitted to the Shabihkhany Hospital of Kashan University of Medical Sciences (Kashan, Iran) in 2010 were enrolled in the present clinical trial. Patients with a history of use of alcohol, drugs, anticonvulsants, antidepressants, benzodiazepines or antihistamines, as well as patients with liver or kidney failure, were

\footnotetext{
${ }^{1}$ Department of Obstetrics and Gynecology; ${ }^{2}$ Trauma Research Centre; ${ }^{3}$ Department of Biostatistics and Public Health, Faculty of Health;

${ }^{4}$ Department of Community Medicine, Kashan University of Medical Sciences, Kashan, Iran

Correspondence: Dr Mohammed Reza Fazel, Matini Hospital, Amirkabir Avenue, Kashan, Iran. Telephone 00-98-913-276-0380,

fax 00-98-361-534-2025, e-mail drmfaze@yahoo.com
} 
TABLE 1

Mean age, duration of surgery and anesthesia, and body mass index of the gabapentin and placebo groups

\begin{tabular}{lccl}
\hline Variable & Gabapentin & Placebo & P \\
\hline Age, years & $43.8 \pm 5$ & $44.6 \pm 5.07$ & 0.57 \\
Duration of surgery, min & $90.4 \pm 18.47$ & $94.6 \pm 17.49$ & 0.41 \\
Duration of anesthesia, min & $119 \pm 16.16$ & $126 \pm 17.61$ & 0.2 \\
Body mass index, $\mathrm{kg} / \mathrm{m}^{2}$ & $24.14 \pm 3.97$ & $25.36 \pm 3.85$ & 0.52 \\
\hline
\end{tabular}

Data presented as mean \pm SD unless otherwise indicated

TABLE 2

Mean pain intensity, measured using a visual analogue scale, experienced by the gabapentin and placebo groups at $2 \mathrm{~h}, 6 \mathrm{~h}, \mathbf{1 2} \mathrm{h}$ and $24 \mathrm{~h}$ after surgery

\begin{tabular}{lccc}
\hline Time after surgery, $\mathbf{h}$ & Gabapentin & Placebo & $\mathbf{P}$ \\
\hline 2 & $6.44 \pm 1.78$ & $8.4 \pm 1.44$ & 0.001 \\
6 & $3.56 \pm 1.5$ & $6.56 \pm 1.8$ & 0.001 \\
12 & $2.48 \pm 1.85$ & $4.6 \pm 1.29$ & 0.001 \\
24 & $0.56 \pm 0.58$ & $1.72 \pm 1.27$ & 0.001 \\
\hline
\end{tabular}

Data presented as mean $\pm S D$ unless otherwise indicated

together with the demographic characteristics of the patients and the duration of surgery, were analyzed using SPSS (IBM Corporation, USA).

A sample size of 25 patients in each group was calculated to detect a significant difference of $15 \%$ in morphine consumption (as derived from pilot data), with a power of $85 \%$ and a significance level of $5 \%$. Statistical tests, such as Student's $t$ test, the Mann-Whitney U test and the $\chi^{2}$ test, were used to assess significant differences between the two groups.

\section{RESULTS}

The two groups showed no significant difference in age, duration of surgery and anesthesia, or body mass index (Table 1 ).

The mean pain intensity at $2 \mathrm{~h}, 6 \mathrm{~h}, 12 \mathrm{~h}$ and $24 \mathrm{~h}$ in the gabapentin group was significantly lower than in the placebo group (Table 2).

The mean $( \pm \mathrm{SD})$ amount of morphine used in the placebo group $(5.2 \pm 2.8 \mathrm{mg})$ was significantly more than in the gabapentin group $(1.2 \pm 0.29 \mathrm{mg} ; \mathrm{P}=0.001)$. There was a significant increase in morphine use in the placebo group (Figure1; $\mathrm{P}=0.001$ ).

In addition, nausea and vomiting were significantly more common in the placebo group compared with the gabapentin group (Table 3).

Finally, the results showed that patients in the gabapentin group recovered earlier, indicated by the time until first ambulation $(12.24 \pm 2.18 \mathrm{~h}$ versus $15 \pm 3.61 \mathrm{~h}$ in the placebo group; $\mathrm{P}=0.002)$.

\section{DISCUSSION}

The present study showed that $1200 \mathrm{mg}$ gabapentin administered $2 \mathrm{~h}$ before surgery reduced pain and opioid consumption and helped the patients to recover more quickly (regain motion) after surgery. Pain after surgery is due to both surgical stimulation and neurogenic factors such as visceral tissue edema. Current pain treatment methods include several analgesic drugs with different mechanisms of treatment (12). Gabapentin is primarily used as an anticonvulsant drug, but recent studies have demonstrated that it also has antihyperalgesic effects (13). Animal studies have demonstrated that presurgical treatment with gabapentin may prevent hyperalgesia and allodynia more effectively than when administered after surgery (14). It is likely that gabapentin mediates this effect through postsynaptic binding to the $\alpha 2$ and $\mu 1$ subunits of the voltage-dependent calcium channels of the dorsal horn neurons in the spinal cord, decreasing calcium entry into the nerve endings and inhibiting the release of neurotransmitters (15).

However, conflicting results exist regarding the effects of gabapentin on pain and narcotic consumption. Turan et al (1) evaluated the effect of $1200 \mathrm{mg}$ gabapentin on pain and tramadol consumption after hysterectomy and found that both parameters were reduced in the gabapentin group. In a study by Durmus et al (8), the effects of $1200 \mathrm{mg}$ gabapentin and gabapentin with acetaminophen were compared with a placebo in

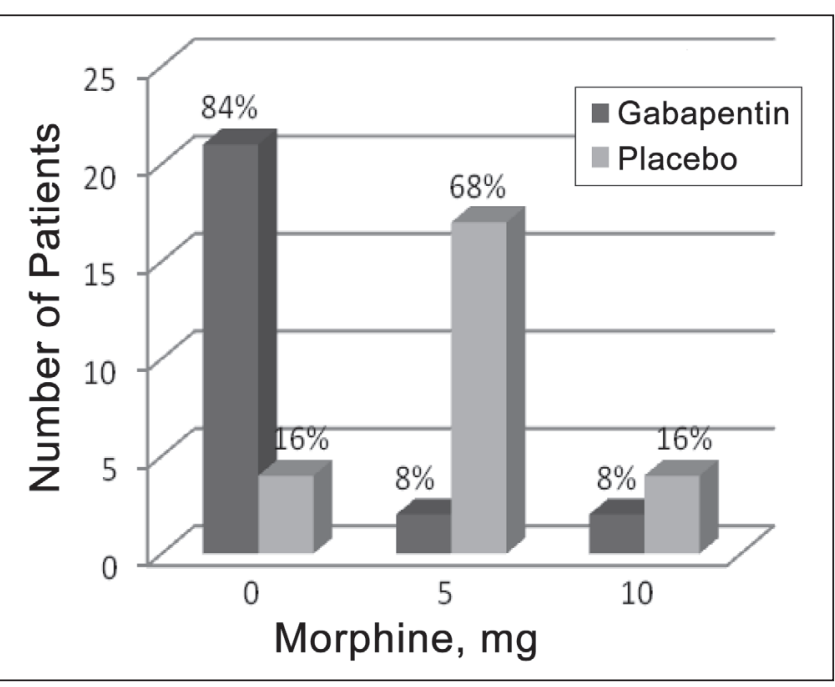

Figure 1) Postoperative morphine consumption in patients in the gabapentin and placebo groups

\section{TABLE 3}

Number of patients experiencing vomiting in the gabapentin and placebo groups at $2 \mathrm{~h}, 6 \mathrm{~h}, 12 \mathrm{~h}$ and $24 \mathrm{~h}$ after surgery

\begin{tabular}{lccc}
\hline Time after surgery, $\mathbf{h}$ & Gabapentin & Placebo & P \\
\hline 2 & 7 & 24 & 0.001 \\
6 & 2 & 11 & 0.001 \\
12 & 3 & 2 & NS \\
24 & 0 & 0 & NS \\
\hline
\end{tabular}

NS Not significant

hysterectomy patients. Pain intensity and morphine requirement decreased in both groups compared with the placebo group, but differences between the gabapentin group and the gabapentin with acetaminophen group were observed only shortly after surgery. Other studies on mastectomy (16) and thyroidectomy (14) revealed similar results.

In contrast to the studies showing a positive effect of gabapentin on pain and opioid consumption, some studies have reported no or low effects. This may be due to confounding factors in experimental design. Dierking et al (17) found no difference in pain after hysterectomy between patients treated with $3000 \mathrm{mg}$ gabapentin and placebo, although they showed that gabapentin decreased morphine consumption by $32 \%$. These results are likely due to either differences in the time of morphine administration, or the fact that each patient in the test group was administered $25 \mathrm{mg} / \mathrm{h}$ of morphine regardless of reported pain level. The placebo group had a mean morphine consumption of $63 \mathrm{mg}$. In our study, morphine was only administered when the patient's pain score rose above 4 . Similarly, in a study by Radhakrishnan et al (2), pain level and opioid consumption were examined after lumbar laminectomy and discectomy in patients receiving either $800 \mathrm{mg}$ gabapentin or a placebo. No difference was observed between groups in terms of pain score or narcotic consumption. However, the investigators used a relatively low dose of gabapentin compared with other studies, which may have been insufficient to prevent sensitization to painful stimuli. Local anesthetic infiltration at the surgical site may also be an important factor. Neural sensitization and hyperalgesia induced by surgical stimulation are blocked using a local anesthetic, which blunts the antihyperalgesic effects of gabapentin.

In a study examining patients undergoing laparoscopic tubal ligation surgery, no significant difference was observed between gabapentin and placebo groups in terms of pain or morphine consumption (18). This lack of effect may have been due to either the administration of $80 \mathrm{mg}$ of lornoxicam, which may have confounded the results, or the time frame in which the gabapentin effect was expected to have occurred. Previous research has shown that gabapentin requires $1 \mathrm{~h}$ to $2 \mathrm{~h}$ to take 
effect; however, the patients examined by Bartholdy et al (18) received gabapentin only $30 \mathrm{~min}$ before surgery. Because the duration of surgery was also quite short ( $30 \mathrm{~min}$ ), there may have been insufficient time for the drug to take effect. Similarly, in a study by Adam et al (19), administering $800 \mathrm{mg}$ of gabapentin to patients undergoing arthroscopic shoulder surgery had no effect on pain or opioid consumption after surgery. However, patients received gabapentin as well as bupivacaine, a drug used for interscalene block (localized nerve blocking), and surgery was performed under general anesthesia. Thus, the use of multiple methods of pain control may have confounded the study results; indeed, synergistic effects between specific drugs have been shown in humans and animals (20). In addition, gabapentin is known to have an anxiolytic effect $(21,22)$. This can reduce preoperative anxiety and result in reduced postoperative pain (23).

Based on these studies, we hypothesize that the effectiveness of gabapentin in postoperative pain management are determined by the following specific factors:

1. Drug dosage according to type of surgery: In various studies, the dose of gabapentin has ranged between $300 \mathrm{mg}$ and $3000 \mathrm{mg}$. The optimal dose may vary according to the type of surgery, the severity of inflammation and tissue damage and the type of pain generated (ie, somatic versus visceral). During surgical discectomy, for example, the optimal dose that reduces pain and opioid usage was reported to be $600 \mathrm{mg}$ before surgery (24). On the other hand, increasing the dose to $1200 \mathrm{mg}$ can lead to complications (2). According to various studies, a dose of $1200 \mathrm{mg}$ before surgery, regardless of the type of action, is

\section{REFERENCES}

1. Turan A, Karamanlioglu B, Memi D, Usar P, Pamukçu Z, Türe M. The analgesic effects of gabapentin after total abdominal hysterectomy. Anesth Analg 2004;98:1370-3.

2. Radhakrishnan M, Bithal PK, Chaturvedi A. Effect of preemptive gabapentin on postoperative pain relief and morphine consumption following lumbar laminectomy and discectomy: A randomized, double-blinded, placebo-controlled study. J Neurosurg Anesthesiol 2005;17:125-8.

3. Rømsing J, Møiniche S. A systemic review of cox-2 inhibitors compared with traditional NSAIDS, or different cox-2 inhibitors for post-operative pain. Acta Anaesthesiol Scand 2004;48:525-46.

4. Field M, Hughes J, Single L. Further evidence for the role of the alpha (2) delta subunit of voltage dependent calcium channels in models of neuropathic pain. Br J Pharmacol 2000;131:282-6.

5. Gee NS, Brown JP, Dissanayake VU, Offord J, Thurlow R, Woodruff GN. The novel anti-convulsant drug gabapentin, binds to the alpha 2-delta subunit of a calcium channel. J Biol Chem 1996;271:5768-76.

6. Backonja M, Beydoun A, Edwards KR, et al. Gabapentin for the symptomatic treatment of painful neuropathy in patients with diabetes mellitus: A randomized controlled trial. JAMA 1998;280:1831-6.

7. Rowbetham M, Harden N, Stacey B, Banstein P, Magnus Miller L. Gabapentin for the treatment of post herpetic neuralgia: A randomized controlled trial. JAMA 1998;280:1873-8.

8. Durmus M, Kadir But A, Saricicek V, Ilksen Toprak H, Ozcan Ersoy M. The post-operative analgesic effects of a combination of gabapentin and paracetamol in patients undergoing abdominal hysterectomy: A randomized clinical trial. Acta Anaesthesiol Scand 2007;51:299-304.

9. Hahn K, Arendt G, Braun JS, et al. A placebo-controlled trial of gabapentin for painful HIV-associated sensory neuropathies. J Neural 2004;251:1260-6.

10. Dirks J, Fredensbory BB, Christensen D, et al. A randomized study of the effects of single dose gabapentin versus placebo on post operative pain and morphine consumption after mastectomy. Anesthesiology 2002;97:560-4.

11. Turan A, Karamanlioglu B, Memis D, et al. Analgesic effects of gabapentin after spinal surgery. Anesthesiology 2004;100:935-8.

12. Parikh HG, Dash SK, Upasani CB. Study of the effect of oral gabapentin used as preemptive analgesia to attenuate post-operative pain in patients undergoing abdominal surgery under general anesthesia. Saudi J Anaesth 2010;4:137-41.

13. Gilron I. Is gabapentin a 'broad-spectrum' analgesic? Anesthesiology 2002;97:537-9. acceptable. Further studies are required to determine the optimal dose of gabapentin in specific surgeries.

2. Timing of administration: Gabapentin crosses the blood-brain barrier and has a therapeutic effect after $2 \mathrm{~h}$ to $3 \mathrm{~h}$ of administration (25). Consequently, it should be administered $1 \mathrm{~h}$ to $2 \mathrm{~h}$ before anesthesia and may not produce the desired result if administered later.

Postoperative nausea and vomiting are common complications of surgery. Gabapentin affects postoperative nausea and vomiting through two mechanisms. The central antiemetic effects are due to reduced consumption of opioids (26). In a study conducted by Al-Mujadi et al (14), only $21 \%$ of patients in the gabapentin group required treatment for vomiting after thyroidectomy surgery, compared with $31 \%$ of patients in the placebo group. Similarly, in a study by Durmus et al (8), the incidence of nausea and vomiting was lower in the gabapentin group. The results of the present study are consistent with these studies in that nausea and vomiting were less common in the gabapentin group compared with the placebo group.

\section{CONCLUSIONS}

The present study shows that $1200 \mathrm{mg}$ of gabapentin reduces postoperative pain and the need for opioids, and enables patients to move more quickly after surgery. Significant side effects were not observed.

ACKNOWLEDGMENTS: The authors thank the personnel of Shabihkhany Hospital for their generous cooperation.

14. Al-Mujadi H, A-Refai AR, Katzarov MG, Dehrab NA, Batra YK, Al-Qattan AR. Preemptive gabapentin reduces postoperative pain and opioid demand following thyroid surgery. Can J Anaesth 2006;53:268-73.

15. Gutton KG, Martin DJ, Pinnock RD. Gabapentin inhibits high threshold calcium channel currents in cultured rat dorsal root ganglion. Br J Pharmacol 2002;135:257-65.

16. Amr YM, Yousef AA. Evaluation of efficacy of the perioperative administration of venlafaxine or gabapentin on acute and chronic postmastectomy pain. Clin J Pain 2010;26:381-5.

17. Dierking G, Duedahl TH, Rasmussen ML, et al. Effects of gabapentin on postoperative morphine consumption and pain after abdominal hysterectomy: A randomized, double-blind trial. Acta Anaesthesiol Scand 2004:48:322-7.

18. Bartholdy J, Hilsted KL, Hjortsoe NC, Engbaek J, Dahl JB. Effect of gabapentin on morphine demand and pain after laparoscopic sterilization using Filshie clips. A double blind randomized clinical trial. BMC Anesthesiol 2006;6:12.

19. Adam F, Ménigaux C, Sessler DI, Chauvin M. A single preoperative dose of gabapentin ( 800 milligrams) does not augment postoperative analgesia in patients given interscalene brachial plexus blocks for arthroscopic shoulder surgery. Anesth Analg 2006;103:1278-82.

20. Eckhardt K, Ammon S, Hofmann U, Riebe A, Gugeler N, Mikus G. Gabapentin enhances the analgesic effect of morphine in healthy volunteers. Anesth Analg 2000;91:185-91.

21. Pollack MH, Matthews J, Scott EL. Gabapentin as a potential treatment for anxiety disorders. Am J Psychiatry 1998;155:992-3.

22. Chouinard G, Beauclair L, Belanger MC. Gabapentin: Long-term anti-anxiety and hypnotic effects in psychiatric patients with comorbid anxiety-related disorders. Can J Psychiatry 1998;43:305.

23. Gilron I, Biederman J, Jhamandas K, Hong M. Gabapentin blocks and reverses antinociceptive morphine tolerance in the rat pawpressure and tail-flick tests. Anesthesiology 2003;98:1288-92.

24. Pandey CK, Navkar DV, Giri PJ, et al. Evaluation of the optimal preemptive dose of gabapentin for postoperative pain relief after lumbar diskectomy: A randomized, double-blind, placebo-controlled study. J Neurosurg Anesthesiol 2005;17:65-8.

25. Welty DF, Schielke GP, Vartanian MG, Taylor CP. Gabapentin anticonvulsant action in rats: Disequilibrium with peak drug concentrations in plasma and brain microdialysate. Epilepsy Res 1993;6:175-81.

26. Rorarius MG, Mennander S, Suominen P, et al. Gabapentin for the prevention of postoperative pain after vaginal hysterectomy. Pain 2004;110:175-81. 


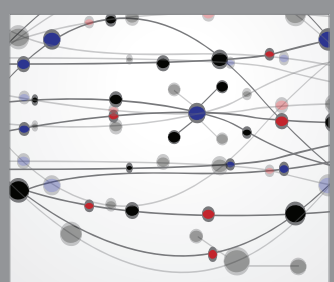

The Scientific World Journal
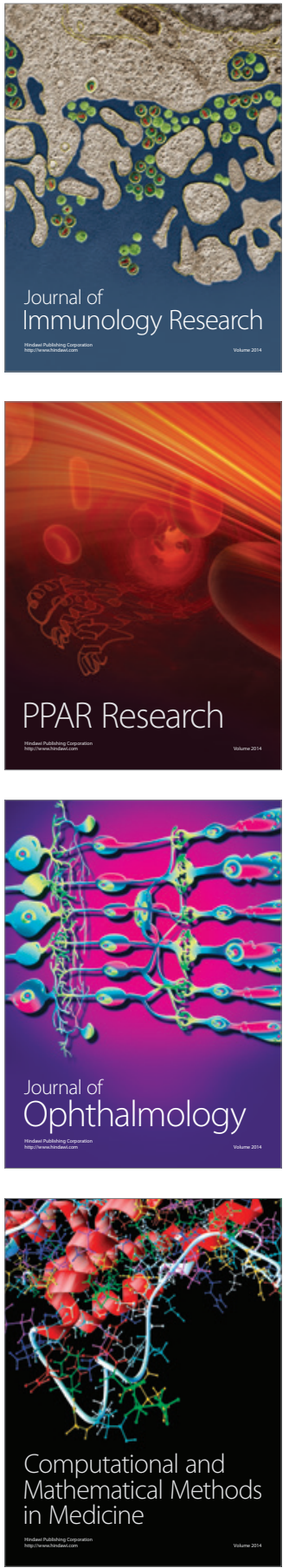

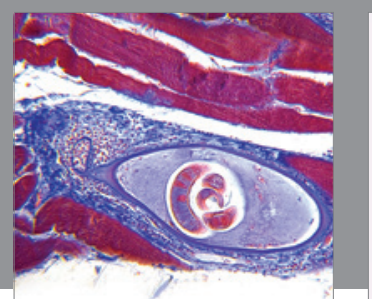

Gastroenterology Research and Practice

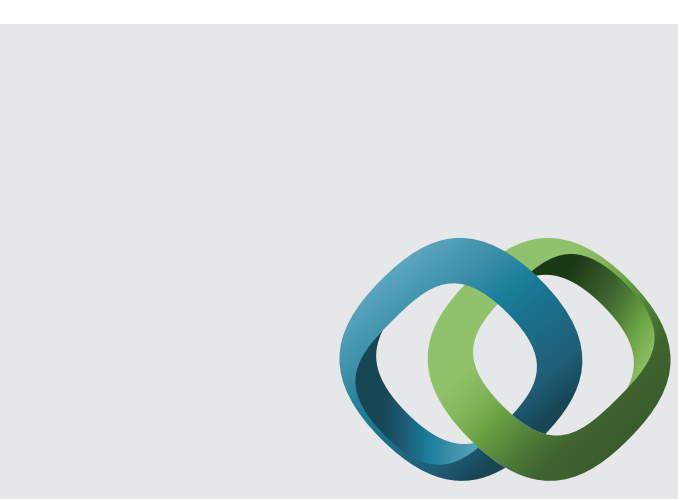

\section{Hindawi}

Submit your manuscripts at

http://www.hindawi.com
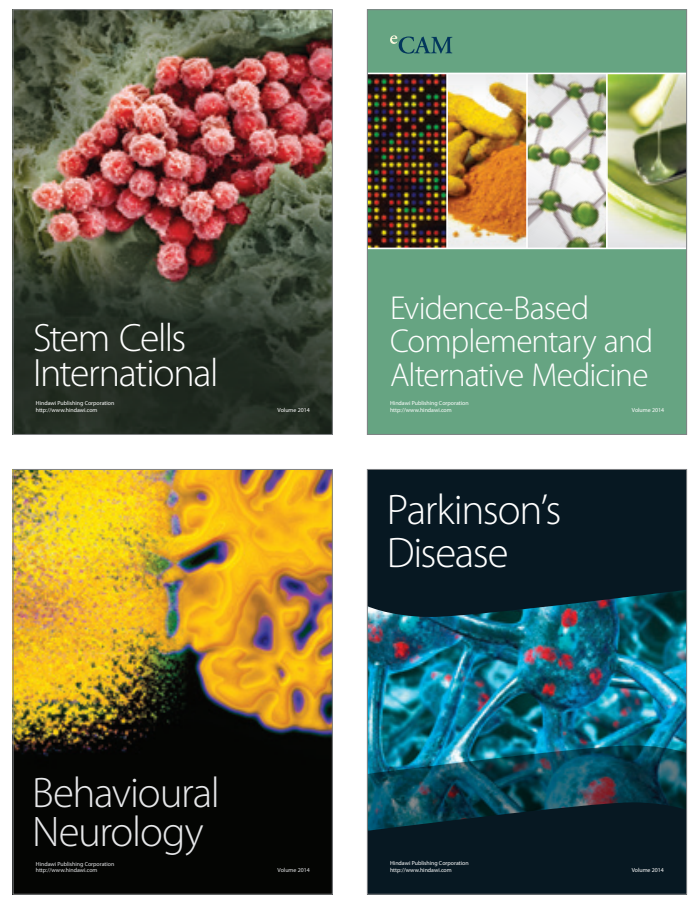
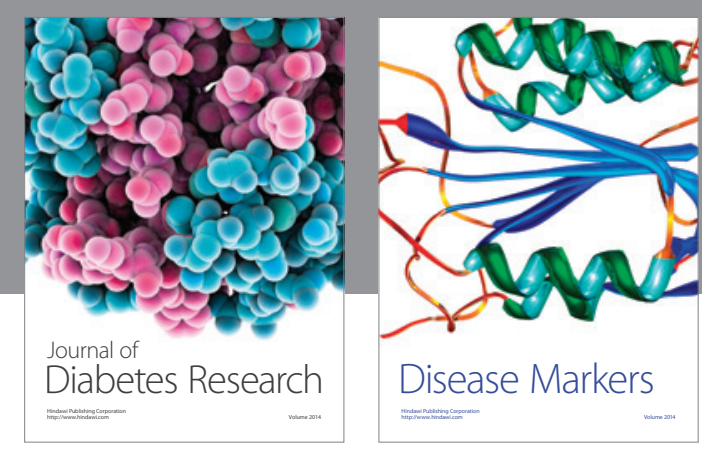

Disease Markers
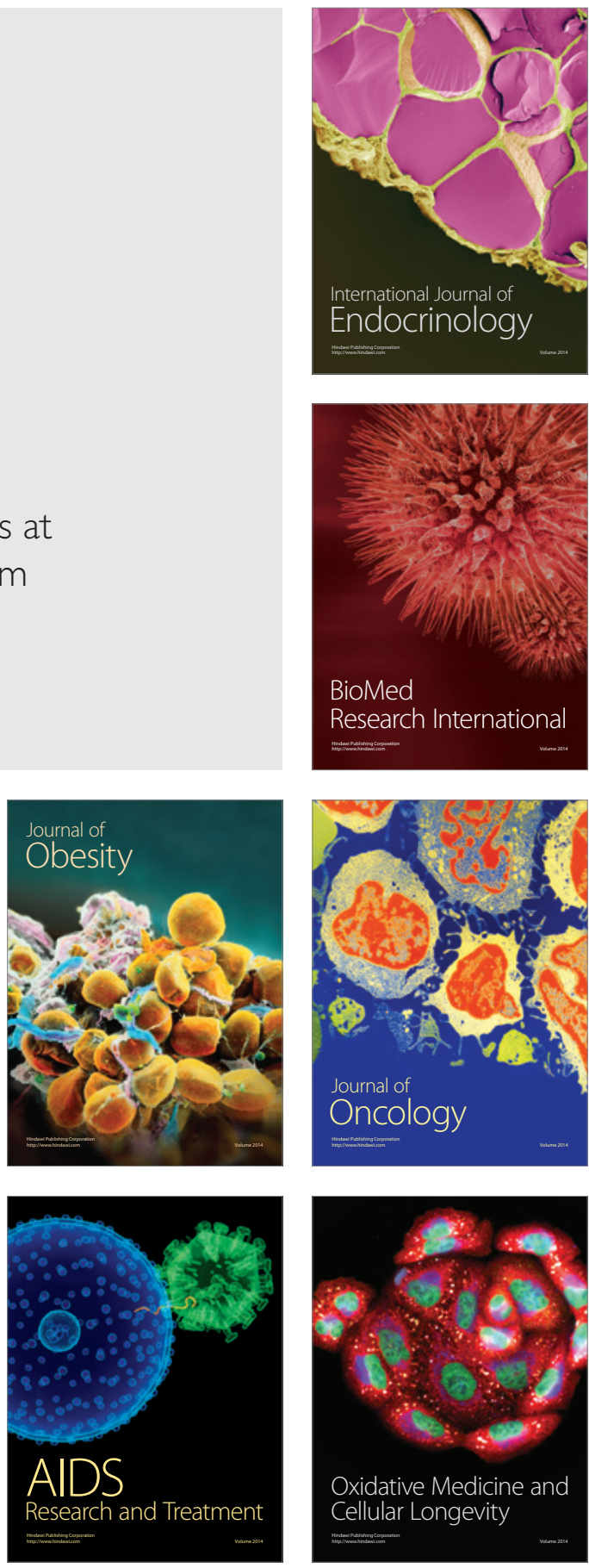